$\begin{array}{lll}\text { KULTURA } & \begin{array}{l}\text { POLSKA A KADEMIANAUK } \\ \text { KOMITET SOCJOLOGII }\end{array} & \text { ISSN 0023-5172 } \\ \text { i } & \begin{array}{l}\text { INSTYTUT STUDIÓW POLITYCZNYCH } \\ \text { SPOLECLENSTHO nr } 2\end{array} & \text { PRZEMIANY WIĘZI }\end{array}$

KAMILA BIAŁY

Uniwersytet Łódzki

\title{
„ROZUMIENIE GRANIC, GRANICE ROZUMIENIA” \\ PARĘ UWAG POKONFERENCYJNYCH NA TEMAT ZWIĄZKÓW MIĘDZY PSYCHOTERAPIĄ A SPOŁECZEŃSTWEM
}

Tematyka konferencji „Rozumienie granic, granice rozumienia”, zorganizowanej przez Uniwersytet Łódzki i Akademię Sztuk Pięknych w Łodzi w kwietniu 2017 roku, ogniskowała się wokół granic — jako kategorii opisującej w sposób szczególny oraz swoisty współczesną rzeczywistość społeczno-kulturową — i różnych ich przejawów $\mathrm{w}$ doświadczeniu jednostek, zwłaszcza $\mathrm{w}$ aspekcie relacyjnym i tożsamościowym ${ }^{1}$. We współczesnym świecie $z$ jednej strony postępują procesy graniczenia, różnicowania, wyodrębniania czy, wreszcie, przekraczania dotychczasowych samookreśleń i form współżycia, które wyznaczają i są wyznaczane przez heterogeniczność, aleatoryczność czy wręcz konfuzję współczesności. Z drugiej zaś obserwujemy równie wyraźne procesy utraty granic i ujednolicania $\mathrm{w}$ ostatecznym rozrachunku projektów siebie i związków z innymi, co jest powiązane z szerszymi społeczno-kulturowymi procesami konflacji i fuzji. Owa dylematyczność i płynność granic nie tylko nie ujmuje im istotności, ale - twierdzić można - sprawia, iż granice tym bardziej stają się kategorią centralną dla rozumienia — „rozumienia granic” — współczesnej rzeczywistości i jej doświadczania przez jednostkę.

Drugi człon tytułu konferencji — „granice rozumienia” — odnosi się do poznawczej możliwości zdania sprawy z zarysowanych wyżej zjawisk. Mówiąc konkretnie, chodziło o rozważenie kwestii stykania się, ale także konfrontowania myślenia psychologicznego i psychoterapeutycznego ze współczesną teorią społeczną, episteme z praxis, w tym zwłaszcza zestawiania diagnozy rzeczywi-

Adres do korespondencji: kamila.bialy@uni.lodz.pl

${ }^{1}$ Zob. pełny program konferencji (http://bit.ly/2o5KUMH). 
stości i różnych jej aspektów z elementami przed- i pozatekstowych sposobów wytwarzania sensu².

Zaproszeni na konferencję psychoterapeuci praktycy mieli zdać relację z tego, jakie kwestie szczególnie zajmują ich pacjentów czy klientów w temacie tak jak przed chwilą zakrojonych granic. Tym samym było to zaproszenie do refleksji nad psychoterapią, jej statusem i granicami współcześnie, w kontekście charakterystycznych dla nowoczesności procesów indywidualizacji. Istotne było pytanie, w jaki sposób psychoterapia może służyć jako środek rozpoznawania rzeczywistości społecznej, zarówno w ramach repertuaru jej psychologicznych narzędzi poznania, jak i jako pole praktyki terapeutycznej, w którym ważną rolę odgrywają atrybuty nieusankcjonowane przez nowożytną naukę, jak związek egzystencjalny, intuicja, wsparcie itp. Do dyskusji wokół tego ostatniego zagadnienia poproszeni zostali także przedstawiciele pola nauki: socjolożka, filozof i psycholożka.

Nie mniej ważne dla organizatorów konferencji było zagadnienie, jaka relacja zachodzi między „rozumieniem granic” a „granicami rozumienia”. Można postawić hipotezę, że występuje homologia/paralelność pomiędzy zarysowanymi wyżej procesami społecznymi, sprawiającymi, iż kategoria granicy zyskuje charakter centralny, a modyfikacjami w obrębie opisu i rozumienia tych przemian, $\mathrm{w}$ wyniku których granice pomiędzy różnymi rozumieniami — oraz być może granice rozumienia rzeczywistości społecznej jako takiej - są równocześnie uelastyczniane oraz stabilizowane. Pytanie to jest tym istotniejsze, iż skutkiem tego procesu może być wszak wytwarzanie się i stabilizowanie odrębnych struktur istotności $\mathrm{w}$ obrębie poszczególnych typów rozumień i wyjaśnień, które mogą nie tylko nie przyczyniać się do rozumienia całościowego współczesnych przemian, ale je wręcz utrudniać.

Zamierzam tu odnieść się tekstów Daniela Bąka, Agnieszki Iwaszkiewicz, Pawła Pieniążka i Barbary Józefik ${ }^{3}$, zarówno praktyków, jak i teoretyków, w trybie metakomentarza, śledząc związki między charakteryzującymi tych autorów różnymi typami rozumienia i wyjaśniania przemian współczesnego świata, czyli w tym przypadku procesów indywidualizacji i zjawiska psychoterapii.

Tekst Daniela Bąka, psychologa i psychoterapeuty, Męsko-męski seks heteryków, czyli społeczno-kulturowy przewodnik po tym, jak go uprawiać i nie zostać gejem dotyczy rozumienia granic męskości, a konkretnie męskich związków w ich

${ }^{2} \mathrm{~W}$ innej pokonferencyjnej publikacji Rozumienie granic. Granice rozumienia. Fenomenologicznie inspirowane interwencje w polu sztuki i humanistyki (Biały, Domański 2018) przedmiotem zainteresowania jest kwestia związków (i granic) łączących i dzielących naukę i sztukę, humanistykę i artystyczne interwencje.

${ }^{3}$ Opublikowane wcześniej w tym zeszycie; zob. Bibliografia. 
różnorodnych społeczno-kulturowych ramach i przykładów tych ram przekraczania. Pod tym kątem autor prześwietla również nowoczesne i ponowoczesne dyskursy terapeutyczne. Dekonstruuje społeczno-kulturowe mechanizmy wymazywania homoseksualności z męsko-męskich interakcji oraz uprawiania męsko-męskiego seksu tak, by nie miał konsekwencji tożsamościowych dla mężczyzny przeżywającego siebie jako heteroseksualnego. W ten sposób odsłania powszechną binarność postrzegania orientacji seksualnej oraz założenie o nieistnieniu biseksualności i/lub systematyczne jej marginalizowanie, podobnie jak wszelkich innych płciowo-seksualnych wymiarów „pomiędzy”. Te społeczne dyskursy przeciwstawia codziennemu doświadczeniu, dowodząc, że „heteronormatywna ideologia nie opisuje sytuacji naturalnej, ale naturalizowaną mającą potwierdzać wrażenie, że opisywany w heteronormie układ ciało/tożsamość stanowi emanację biologicznej esencji”. Analogicznie, „stare” dyskursy psychiatryczne i psychoterapeutyczne w interesującym autora płciowo-seksualnym aspekcie są kontrastowane $z$ „nowymi”. Najwyraźniej widać to w odejściu od dotychczasowego terminu „orientacja seksualna” i wzroście popularności i stosowalności terminu „tożsamość seksualna”, akcentującego subiektywność przeżywania własnej płciowości i seksualności.

Chociaż Bąk zaznacza, że nie chodzi mu o „ustanowienie nowej normatywności wprowadzającej płynność i niestabilność męskiej seksualności jako pożądany standard", to jednak taki jest do pewnego stopnia wydźwięk jego artykułu. Codzienne doświadczenie mężczyzn czy ich konkretne i subiektywne doświadczenia opowiadane w gabinecie psychoterapeutycznym stanowią bez wątpienia pewną rzeczywistość, o której nie tylko warto, ale trzeba mówić. Podparte to zostaje argumentacją naukową, badaniami i koncepcjami, i w ten sposób staje się - najpewniej w sposób zamierzony — stanowiskiem w sporze o racje, nabierając tym samym cech dyskursu $\mathrm{z}$ własną normatywnością. I nie ma $\mathrm{w}$ tym nic nadzwyczajnego. Zwraca natomiast uwagę to, i jest to najpewniej niezamierzone, że uczestnictwo w sporze zatraca do pewnego stopnia swój swoiście poznawczy/konstruktywny charakter. Dekonstrukcja staje się polityczna przez swoją instrumentalność i reaktywność, zachowując tym samym moc rażenia, ale wytracając moc poznawczą płynącą z pola doświadczeniowego, fenomenologicznego, a także interpretatywnego. To najpewniej mamy na myśli, gdy za poststrukturalistami w rodzaju Foucaulta twierdzimy, że rządzą nami dyskursy, ale też że dyskurs krytyczny, na co wskazywał już Nietzsche, ma swój regresywny aspekt.

Paradygmat interpretatywny i dekonstrukcja w naukach społecznych, a tak$\dot{z}$ e fenomenologiczna epistemologia $\mathrm{w}$ psychoterapii zostają tu użyte, jak można sądzić, w kontekście ogólnego wydźwięku tekstu - jako filtr jedynie słusznej prawdy. Zacznijmy od drobnych semantycznych markerów waloryzowania, odróżniania prawdy od fałszu: „obrazy”, „kulturowe fantazje o mężczyznach oraz ich seksualności” przeciwstawione są tu „codziennemu doświadczeniu” i „męskim życiorysom”. Bardziej zasadniczą kwestią jest jednak wykorzystanie 
do normatywizowania normalizacji: po pierwsze, konstruktu tożsamości seksualnej, czyli między innymi sposobów, w jakie „ludzie na fundamencie biologicznych uwarunkowań stwarzają swoje płciowo-seksualne Ja w procesie jego ko-kreacji ze środowiskiem społeczno-kulturowym, w którym żyją"; po drugie, doświadczenia fenomenologicznego: „Dlaczego zakładamy, że [...] [przypadki męsko-męskiego seksu mężczyzn hetrroseksualnych, np. mężowie mający romanse $z$ kolegami z pracy, aktorzy porno mający partnerki - przyp. K.B.] nie mogą być nacechowane intymnością i/lub przeżyciem seksualno-emocjonalnej przyjemności i satysfakcji?”, i wreszcie paradygmatu dekonstrukcjonistycznego: „Łatwo można dostrzec, że heteronorma marginalizuje doświadczenie wszystkich tych osób, które na poszczególnych wymiarach płciowo-seksualnego Ja znajdują się pomiędzy biegunami, czyli interseksualnych, transgenderowych, androgynicznych, biseksualnych i aseksualnych".

Bąk korzysta w swojej argumentacji także z założeń psychoterapii Gestalt. Czytamy: „Selfing to branie życia takim, jakie jest. Bez «centralnego sterowania» w postaci heteronormatywnych konstruktów. Szłaby za tym większa wolność w decydowaniu o sobie, myśleniu o sobie oraz przeżywaniu własnej osoby, także większa odpowiedzialność za siebie w relacjach. Jeśli ktoś jest gotów”. Nie wchodząc w założenia tej orientacji psychoterapeutycznej można zadać pytanie, jak możliwe jest zupełne abstrahowanie od kontekstu, od heteronormatywnych konstruktów? Dlaczego nie pojawia się tu - w wypowiedzi nawykłego i wrażliwego nań z pewnością psychoterapeuty - kwestia trudności tego procesu, cierpienia związanego $z$ konfrontowaniem się $z$ heteronormą, a akcent położony jest, jak w reaktywnej niezgodzie, na (bezproblematyczną) wolność, a od niej z kolei następuje przeskok, niejako automatyczny, do odpowiedzialności? Czym jest ta odpowiedzialność „za siebie w relacjach”? Relatywnie dużo tu ostrych przejść, podziałów i rozgraniczeń, mimo że autor jest świadom obcowania z płynną współcześnie materią ludzkich relacji i tożsamości. Żadna perspektywa nie może dominować w rzeczywistości, w której znaczenia mają płynny i niepewny status, a interpretacja jest jedynym sposobem porozumiewania się z innymi (Orange 1995).

Skoro o płynności granic mowa, to być może tekst zyskałby na przejrzystości, gdyby autor określił go jako jednoznacznie aktywistyczny lub terapeutyczny. Ten pierwszy nie musiałby wszak zawierać koncesji na rzecz drugiej strony sporu, mógłby być otwarcie polityczny, perswazyjny, posługując się dowolnie prowokacją i innymi retorycznymi chwytami. Ten drugi zaś - jako oparty na materiale gabinetowym - mógłby być tekstem fenomenologicznym, może do pewnego stopnia autoetnograficznym. Nie chodziłoby o szukanie dowodów ani o racje, ale o zdanie sprawy z życiowej/ludzkiej sytuacji, jak to jest być współcześnie człowiekiem. Oczywiście wiedzieć, co znaczy być człowiekiem, nie równa się automatycznie umieć o tym mówić, zwłaszcza że gubi się przy tym prywatny i pewny charakter doświadczenia. Odwieczny to problem, jak wyrazić w języku, więc upublicznić i urzeczowić fenomenalne doświadczenie; 
jak z ruchu „do rzeczy” przejść do języka, perswazyjnego z samej swej natury, i z powrotem do rzeczy (Wiesing 2016)? Być może w głosie Bąka zabrakło tego ostatniego, to jest powrotu do fenomenu/do praktyki, i wyjścia z pola walki na interpretacje?

Artykuł psychoterapeutki, Agnieszki Iwaszkiewicz, Czy Brandon Sullivan powinien się wstydzić? Granica między patologia a życiem powstał na kanwie filmu Wstyd, który traktuje ona jako pretekst do pytań dotyczących istoty oraz celu współczesnej psychoterapii, czyli jej granic, a konkretem empirycznym służącym do odpowiedzi na nie są związki/relacje intymne i ich różne manifestacje.

Autorka przeciwstawia dyskursy normatywizujące dyskursom normalizującym, choć - podobnie jak Daniel Bąk - tych drugich dyskursami nie nazywa. $\mathrm{Z}$ jednej strony jest więc, jak to określa, „[...] ubolewanie nad stanem współczesnych związków intymnych: niezobowiązujący seks, powierzchowność relacji sprowadzonych tylko do tej sfery, pozorna dostępność partnerów na licznych portalach randkowych [...], wreszcie single i ich styl życia", pod którym można odnaleźć dekonstruowane przez autorkę przekonanie, że „związki intymne i umiejętność ich utrzymania mogą stać się definicją dobrostanu lub życiowej porażki". Do tych normatywizujących dyskursów dokooptowane są — na zasadzie podobieństwa formalnego - „stare” dyskursy terapeutyczne: dla terapeuty pytanie o związki intymne jest diagnostyczne, gdyż pozwala dostrzec: „,...] narcyzm, lękowo-unikający lub zdezorganizowany styl przywiązania, omnipotencję, maniakalne rozwiązania, ucieczkę od zależności [...] wreszcie perwersyjny charakter zachowań".

$Z$ drugiej strony Iwaszkiewicz zastanawia się — nie bez racji — nad postawą, która chroni „świadomie skonstruowane życie i wybory” (indywidualizm versus zależność) lub współczesne związki przed „krzywym zwierciadłem, w którym pokazywana jest jedynie karykatura człowieka i jego ludzkiej kondycji”. W celu ilustracji tego dylematu psychoterapeuty wybiera postać filmową, Brandona, dość prowokacyjnie postanawiając bronić jego „harmonijnego”, choć „niekonwencjonalnego" życia przed jednoznacznymi ramami, w jakie wtłacza go reżyser (typowy dla singla promiskuityzm, w dyskursie terapeutycznym zaś „maniakalność”, w filmie finalizuje się w aurze „delirium, cierpienia i martwoty”).

Opisywany przez oboje terapeutów świat jest w dużej mierze światem bez cierpienia i (dlatego) wolności od opresyjnych norm powodujących wstyd i/lub winę. Trudno nie zaklasyfikować ich głosów, co czyni kolejny autor, Paweł Pieniążek, jako swoistych dla dyskursu relatywistycznego, który wcześniej został określony jako normatywizujący normalizację. A przecież oboje praktycy, bez względu na orientację terapeutyczną, niemal nieustannie spotykają w gabinecie cierpienie wywołane między innymi społeczno-kulturowymi normami i najpewniej są świadomi siły oddziaływania tych norm, przyglądają się ich funkcjom, szukając z pacjentami odpowiedzi. Dlaczego nie wybrzmiewa to w ich głosie? Każe się nad tym zastanowić kolejny artykuł Transgresje nowoczesności autorstwa filozofa Pawła Pieniążka, stanowiący metakomentarz do wypowiedzi 
psychoterapeutów. Psychoterapia jest w nim rozpatrywana również jako dyskurs kulturowy w kontekście nowoczesnych procesów indywidualizacji, które zostają dość szeroko omówione. Na końcu tego omówienia autor przedstawia dwie tendencje obecne, jego zdaniem, w psychoterapii i stojące za nimi dwie różne filozofie człowieka: pierwszą, mającą na celu „«uzdrowienie» jednostki poprzez pobudzenie jej jednostkowej egzystencji, umożliwienie jej samorozwoju, samorealizacji, wyzwolenie jej twórczego potencjału, nawet za cenę konfliktu ze społeczeństwem”; i drugą, prowadzącą „do uspołecznienia jednostki, czyli takiego jej uzdrowienia, które pozwalałoby na bezkonfliktową koegzystencję". Przeciwstawienie sobie tych orientacji pozwala mu w kolejnym kroku odnieść się do głosów dwójki praktyków i dokonać ich dekonstrukcji w sposób wzbogacający odbiorcę, ale i społeczną samowiedzę, z wykorzystaniem koncepcji transgresji George'a Bataille'a.

Trudno o inny werdykt niż taki, że teksty dwójki psychoterapeutów są ilustracją relatywizacji i legitymizowania relatywizacji, czyli stwarzania wariantywnego obszaru normatywności. Domena subiektywności z pewnych powodów nie jest tu dostatecznie komunikowana w języku, na co zwróciłam już uwagę, częściowo zostaje w ten język w naturalny sposób uwikłana, stając się stroną sporu, i wreszcie, w dalszej kolejności, nie stanowi podstawy do rozwinięcia możliwie rozmaitych i złożonych hermeneutyk, w tym kluczowych tutaj zagadnień autonomii i odpowiedzialności.

W tym kontekście współczesna psychoterapia wymyka się, o czym pisze Barbara Józefik, podziałowi zaproponowanemu przez Pawła Pieniążka na „konformizującą” i „konfliktującą", gdyż jest współkształtowana przez dyskursy innych pól, w tym przez współczesną filozofię. Tak zwany paradygmat relacyjny rozwija się $\mathrm{w}$ poprzek dotychczasowych psychoterapeutycznych orientacji; akcentuje pewną epistemologiczną ciągłość, która charakteryzuje też zamysł Bataille’a, czyli łączenie autonomii i odpowiedzialności, motywu indywidualistycznego i społecznego, zmiany i ciągłości (Stark 1999; Spagnuolo Lobb 2016). Szczególnie wpływowa stała się, zarówno w nurtach psychoanalitycznych, jak i humanistycznych, myśl Levinasa; jest ona również inspiracją dla poststrukturalistów, zwłaszcza Derridy, jeśli chodzi o pojęcie transgresji. Nie zarzuca się więc autonomii, ale się ją radykalizuje i pogłębia w relacji z Innym, która jest zawsze relacją etyczną, a więc doświadczeniem zakładającym heteronomię (Critchley 2012).

Innymi słowy, spotkanie $z$ Innym to spotkanie z różnicą, a moment, w którym dąży się do podobieństwa, jest potencjalnie momentem opresji, kontroli i władzy. Tym, co wspólne zarówno dla psychoanalizy po Freudzie i psychoterapii Gestalt, jak i dla transgresji Bataille'a czy poststrukturalistów, jest nie tyle pacyfikacja konfliktu (która w prosty sposób prowadzi do konformizmu), ile nań każdorazowe nakierowanie. Pojawia się pytanie, czy ten konflikt w naturalny sposób nie przechodzi przez fazę buntu, buntu reaktywnego/konformizującego. Stawanie się naprawdę sobą (samourzeczywistnianie) związane jest 
bowiem z pokonywaniem lęku separacyjnego (Rank 1989; Fromm 2013), czyli przekraczaniem normy ku postawie utrzymującej ambiwalencję normy. Tak zwana paradoksalna teoria zmiany, koncepcja stosowana w psychoterapii, mówi, że zmiana następuje wtedy, gdy ktoś staje się tym, kim jest, a nie usiłuje się stać tym, kim nie jest; innymi słowy, tylko akceptując normę (dodajmy, po fazie buntu wobec niej), mogę zacząć ją przekraczać i w ten sposób będę się zmieniać (Beisser 1988).

Po to zaś, by móc się spot(y)kać w różnicy, móc się konfliktować, potrzebne jest $-z$ perspektywy psychoterapeutycznej — wsparcie, ale też potrzebna jest stabilna tożsamość i trwałe więzi społeczne, których współczesne płynne społeczeństwo, manifestując się poprzez swoje nowoczesne instytucje, jak państwo, prawo, biurokracja, a także korporacje, nie daje, lecz coraz bardziej i totalnie się instytucjonalizuje, o czym pisze też Pieniążek. Bataille'owska ambiwalencja zarazem usunięcie normy i jej nieobalenie - była skrojona na inne nowożytne czasy, dlatego formułowanie pesymistycznych diagnoz na temat współczesności z tej perspektywy, w tym dewaluowanie jakości oporu — jako finalizującego się $\mathrm{w}$ postawie konformizmu, przynosi ryzyko zawężenia pola widzenia i może skutkować z jeszcze inną postawą, czyli wycofaniem z rzeczywistości, a nie $\mathrm{w}$ nią zaangażowaniem.

Wobec wyjściowych różnic, ale także zaskakująco wielu epistemologicznych podobieństw dziwi, że napięcie istniejące między praktykami i teoretykami nie rozwija się w żadnym kierunku, strony raczej osadzają się, ze względu na wzajemne koluzyjne sprzężenia, bądź w konformizmie (brak granic), bądź w wycofaniu (sztywne granice), czyli każda pozostaje przy swego rodzaju reaktywnym buncie wobec drugiej, co opisują odnosząc się do rzeczywistości gabinetowej i społecznej. Zjawisko fuzyjności czy, jak to określa Luhmann, dedyferencjacji współczesnych procesów społeczno-kulturowych jest przeciwieństwem konfliktu, ale stabilizuje je również konflikt rytualny, w którym strony reprezentują awers i rewers tego samego medalu, są zlane $z$ rzeczywistością bądź $z$ niej wyizolowane, a role te mogą być dynamicznie zmienne. Znika uważność i czujność wobec rzeczywistego przedmiotu zaangażowania, wobec projektów ewentualnej rekonstrukcji w wyniku tej ciągłej, w końcu nie bezzasadnej dekonstrukcji, a poprzez ich realizację — gotowość na ciągle potrzebne nowe projekty dekonstrukcji. Odnosząc do konkretu można powiedzieć, że jest co i będzie co krytykować w obszarze psychoterapii. Społeczna krytyka musi być jednak zainteresowana psychoterapeutycznymi fenomenami (trudnymi do przełożenia na język w ogólności, a i w tym reaktywnym kontekście) i dyskusją w środowisku psychoterapeutycznym. Zwłaszcza jeśli weźmie się pod uwagę, że ten krytykowany relatywizm ma kontekst, stanowi odpowiedź — dekonstrukcję właśnie na to, co przez dekady było i nadal jest obecne w środowisku terapeutycznym i w społeczeństwie. Przyjrzyjmy się, zamiast zakończenia, poczynionej na bardzo ogólnym poziomie, ale jednak próbie wyjścia poza ten spór między praxis a episteme i zwróćmy uwagę na inne konstruktywne aspekty związków między 
psychoterapią a społeczeństwem oraz między różnymi typami rozumienia i wyjaśniania.

Z kolei Barbara Józefik w tekście Dyskursy psychoterapii a rozumienie rzeczywistości społecznej przedstawia psychoterapię jako dyskurs kulturowy. Umieszcza ją ją wśród innych dyskursów, w tym dyskursów naukowych, tym samym wskazując na krytyczną refleksję w psychoterapii nad jej własną rolą i statusem we współczesności. Autorka podejmuje też - jako jedyna z czwórki przedstawionych tu autorów - próbę rozumienia kultury i zjawisk społecznych z perspektywy psychologicznej i psychoterapeutycznej.

Dwie role - praktyka i teoretyka - z których wypowiada się Józefik, pozwalają jej w pewnym sensie weryfikować wzajemnie obie perspektywy i unikać jednostronności. Józefik zaczyna od tego, że dyskursy „stanowią podstawę myślenia psychoterapeutów i podejmowanych przez nich praktyk" i, co z tym się łączy, że „[w]ładza jest obecna w relacji psychoterapeutycznej, zarówno w tych podejściach, które zakładają hierarchiczność relacji, jak i terapiach ponowoczesnych, które starają się tę władzę w procesie psychoterapeutycznym dekonstruować". Prostą konsekwencją jest więc, pokazuje dalej autorka, że psychoterapia i różne jej podejścia, a także inne, jak je nazywa, „pokrewne dziedziny”, w tym psychiatria, psychologia, filozofia, neuronauka, biologia, socjologia, są dzieckiem swoich czasów: „Podejścia te zgodnie z własnymi założeniami, założeniami dziedzin pokrewnych i kontekstem kulturowym definiują, co jest normą, co jest prawidłowe, a co jest zaburzeniem".

Autorka rozwodzi się szerzej - co zresztą zrozumiałe, gdy spojrzeć na stan refleksji nad konstrukcjonizmem w środowiskach psychiatrycznych — nad zjawiskiem medykalizacji i psychiatryzacji niż nad tendencją do normalizacji w psychoterapii. Ostatecznie wraca do zagadnienia odpowiedzialności, tu odpowiedzialności zawodowej, co mniej dochodziło do głosu w wypowiedziach pozostałych praktyków. Wielość zróżnicowanych modeli życia dostępnych we współczesnej kulturze stawia przed psychoterapeutami — stwierdza Józefik konieczność „[...] precyzyjnego zdefiniowania własnej pozycji epistemologicznej, badania konsekwencji jej uznania i przyjęcia na siebie odpowiedzialności za działania $z$ tego wynikające". Założenia epistemologiczne mają bowiem daleko idące konsekwencje praktyczne, teoretyczne, etyczne i prawne.

Barbara Józefik podejmuje też nieobecny u jej poprzedników wątek: jak $z$ perspektywy gabinetu psychoterapeutycznego można próbować rozumieć kulturę i zjawiska społeczne. Warto zwrócić uwagę nie tylko na to, w jaki sposób psychoterapia i myślenie psychologiczne może stać się środkiem rozpoznawania rzeczywistości społecznej, o czym szczegółowo i ciekawie pisze autorka, ale na to, że wątek ten jest nieobecny w trzech innych wypowiedziach. Różne są tego powody, ale kontekstowo można widzieć to tak, że pozostali autorzy zajmują się dekonstruowaniem, i mają w tym wiele racji, ale ten spór woła o kolejny krok. Może przybliża do tego powyższy metakomentarz, w którym strony mogą się przejrzeć. 


\title{
BIBLIOGRAFIA
}

Beisser Arnold R., 1990, Flying Without Wings: Personal Reflections on Loss, Disability, and Healing, Bantham Books, New York.

Biały Kamila, Domański Marek (red.), 2018, Rozumienie granic. Granice rozumienia. Fenomenologicznie inspirowane interwencje w polu sztuki i humanistyki, Akademia Sztuk Pięknych w Łodzi, Łódź.

Critchley Simon, 2012, Infinitely Demanding: Ethics of Commitment, Politics of Resistance, Verso, London-New York.

Fromm Erich, 2013, Patologia normalności. Przyczynek do nauki o człowieku, tłum. Stefan Baranowski, Robert Palusiński, Vis-à-vis/Etiuda, Kraków.

Orange Donna, 1995, Emotional Understanding: Studies in Psychoanalytic Epistemology, Guilford Press, New York.

Rank Otto, 1989, Art and Artist: Creative Urge and Personality Development, Norton, New York-London.

Spagnuolo Lobb Margherita, 2016, Podstawy i rozwój psychoterapii Gestalt we wspótczesnym kontekście, w: Gianni Francesetti, Michela Gecele, Jan Roubal (red.), Psychoterapia Gestalt w praktyce klinicznej: od psychopatologii do estetyki kontaktu, tłum. różni, Harmonia Universalis, Gdańsk.

Stark Martha, 2000, Modes of Therapeutic Action: Enhancement of Knowledge, Provision of Experience, and Engagement in Relationship, Jason Aronson, Northvale, NJ.

Wiesing Lambert, 2016, The Philosophy of Perception: Phenomenology and Image Theory, Bloomsbury, London.

Daniel Bąk, 2018, Męsko-męski seks heteryków, czyli społeczno-kulturowy. przewodnik po tym, jak go uprawiać i nie zostać gejem, „Kultura i Społeczeństwo”, nr 2 (s. 185-196 w tym tomie).

Agnieszka Iwaszkiewicz, 2018, Czy Brandon Sullivan powinien się wstydzić? Granica między patologia a życiem, „Kultura i Społeczeństwo”, nr 2 (s. 197-202 w tym tomie).

Barbara Józefik, 2018, Dyskursy psychoterapii a rozumienie rzeczywistości społecznej, „Kultura i Społeczeństwo", nr 2 (s. 213-221 w tym tomie).

Paweł Pieniążek, 2018, Transgresje nowoczesności, „Kultura i Społeczeństwo”, nr 2 (s. 203-212 w tym tomie).

\section{UNDERSTANDING LIMITS-THE LIMITS OF UNDERSTANDING: POST-CONFERENCE REMARKS ON THE LINKS BETWEEN PSYCHOTHERAPY AND SOCIETY}

\author{
Kamila Biały \\ (University of Łódź) \\ Summary
}

This article contains meta-commentary on the statements of theoreticians and practitioners concerning the connections between psychotherapy and changes in contemporary society in regard to identity and relations. It also concerns various types of understanding of these areas ensuing from the field of practice and the field of science, and the connections being produced between them, including those that are unintended. 
Key words / słowa kluczowe

boundaries / granice, understanding / rozumienie, psychotherapy / psychoterapia, deconstruction / dekonstrukcja, resistance / bunt, reactivity / reaktywność, conflict / konflikt 